\title{
Philosophical Pedagogy in the Service of Ideology in the Times of the Polish People's Republic
}

\section{Katarzyna Wrońska ${ }^{a}$}

a

\section{Department of General Pedagogy and the Philosophy of Education katarzyna.wronska@uj.edu.pl}

Jagiellonian University in Cracow,

Received 1 November 2020

Accepted 28 March 2021

Available online 31 August 2021

DOI 10.15240/tul/006/2021-1-010

Abstract In my paper, I would like to consider the problem of entanglement of philosophy of education in the communist ideology. I will show it on the example of one Polish concept, created by Karol Kotłowski. He was a disciple of Sergiusz Hessen and developed his own concept of philosophical pedagogy, presenting the philosophy of dialectical materialism, that is Marxism as a perspective in which the entire philosophical thought culminates. Reading Kotłowski, we can see, on the one hand, his rooting in broad philosophical thought, on the other hand - his adherence to the ideology of the socialist state, which demands that education serve the political system and prepare people to be the builders of the system. The theoretical basis for my analysis is Arendt's concept of totalitarianism and Tischner's view of homo sovieticus. The analysis is preceded with an historical overview of the situation in Poland in the first decade after World War II with reference to academic pedagogy.

Keywords philosophical pedagogy; Marxism; ideology of the socialist state; education

\section{Introduction}

Education in the hands of the state has a long history. From the Polish perspective, the worst associations it evokes are the policies of invaders towards the Polish population during the Partitions of Poland. These include denationalisation, Germanization, Russification and subordination to monarchy. A completely different picture presents itself when we look at the way how the state organized education after Poland regained its independence in 1918. At that time, the Polish state engaged in the reconstruction of all the subsystems that made up the entire reborn of the state and nation, including the reform 
of education. The pedagogy of that time boasted a great openness to the trends developed throughout Europe and America, not only in research on education but also more widely in the humanities and social sciences. Philosophical pedagogy was already competing with empirical, psychological and sociological pedagogy, but also with different varieties of ideological pedagogy (Wołoszyn, 1998). There was therefore no shortage of criticism of the state's educational policy, which was allegedly imposing its own patterns on the minds of the young generation (Kozłowski, 1932, Wrońska, 2020). Today, the Polish state is again pursuing an intensive educational policy with injurious consequences for pedagogy. Pedagogy is regarded either as superfluous or newly necessary and subservient: the former if it does not adapt itself to the educational goals of the state; the latter if it can be made to serve these goals.

In this paper I would like to look at a period "in between", i.e. the Polish People's Republic (1945-1989) when academic pedagogy, pushed onto the margins of research on education, was assigned tasks strictly connected with building a new system in Polish society, precisely by means of upbringing (cf. Friedrich \& Brzeziński, 1965). How did it perform its role in training educators and teachers, and to what extent was it helped by philosophical reflection? Does not today's ideological offensive of the right-wing government in Poland begin to resemble the past period of communism? Are we, as educators, immune to it, and how helpful can cooperation between pedagogy and philosophy be (or practicing pedagogy as both social and humanistic science of humankind)? What lesson can we learn from that period as educators, both practitioners and theoreticians? The system of totalitarian communist power did not leave an open space for independent thought (not to mention one critical of the ideology of power) and this had to affect not only pedagogy as such but also philosophical pedagogy. I would like to examine the "in between period" by looking at the views and activities of Karol Kotłowski (1910-1988), a student of Sergei Hessen and creator of philosophical pedagogy of the times of the Polish People's Republic recognised by the state authorities. In addition to making explicit how pedagogical research and practice during this period were constrained 
to serve the interests of the communist state, some telling lessons for today may be uncovered, both for Poland and other countries.

In order to face up to this task and to answer the questions formulated, I propose the following plan. To begin with, I will present a summary of historical events and political decisions which are the background for academic pedagogy and the training of educators in Poland after the end of the World War II. Then I will present theoretical approaches on which I will base my analysis of the pedagogical concepts developed by Kotłowski. The analysis will draw firstly on Hannah Arendt's historical-philosophy research on totalitarianism and Józef Tischner's concept of homo sovieticus, then it will avail of Sergei Hessen's distinction between philosophy and ideology. Against this historical and theoretical background, I will present the silhouette of Kotłowski and his research activity, and strictly speaking, his own concept of philosophical pedagogy practiced at the University of Łódź. I will focus primarily on his axiological assumptions in this normative pedagogy, including these: proletarian humanism and collectivism, internationalism, as well as self-discipline and respect for social property, thanks to which pedagogy (by instilling these values in pupils and teaching them to their parents as well) could help to consolidate the new socio-political system. In such a manner, I will attempt to show that Kotłowski's philosophical pedagogy was a Marxist pedagogy, serving to build a new socialist model of society, dependent on state power and ultimately ideological. In addition to evaluating the work of Kotłowski, I would also like to highlight some ways of preventing the recurrence of totalitarianism - political or educational - and to highlight the part to be played by pedagogy in this event. The period of the Polish People's Republic has been widely explored. Latest research in social sciences and humanities allows us to see various aspects of life in Poland and other communist countries after World War II, not limited to the perspective on 20th century totalitarianisms (e.g. Bren \& Neuburger, 2012, Giustino, Plum \& Vari, 2013, Klich-Kluczewska, 2017). 


\section{A Historical Glance at Polish Pedagogy and Pedagogical Training in the Early Communist Era}

The open ideological offensive on education in Poland did not start immediately after the country regained its independence (Wołoszyn, 1964, p. 738, Szulakiewicz, 2006, pp. 43-44). Until 1948, universities employed pre-war scholars as well as professors connected with the Universities of Lviv and Vilnius before the war. The University of Łódź was founded in 1945, building, inter alia, on the work of the branch of the Wolna Wszechnica Polska (Free Polish University) that had operated there in the interwar period. Kotłowski conducted his scientific activity here in the years 1947-1980 (Szulakiewicz, 2006, pp. 205-206). Although Łódź did not have a university tradition, it was here where such scholars as Sergei Hessen, Bogdan Nawroczyński, Helena Radlińska and Bogdan Suchodolski worked immediately after the war (Kotłowski, 1976b, p. 119). They did so only briefly, because in 1948 the ruling Communist Party, not seeing enough support from scholars for the state authorities (Mauersberg, 1981, p. 327), intensified its actions to subordinate education and science (including pedagogy) to Marxist-Leninist ideology, i.e. the policy of totalitarian state (Hejnicka-Bezwińska, 2015, pp. 117-142; Okoń, 2003, p. 297). According to Wincenty Okoń, another student of Hessen, and his description of the situation at the University of Łódź, in 1948, his master Hessen was dismissed as the Chair of General Pedagogy. It was taken over by Dr. Marian Gluth, who guaranteed a new line of pedagogy and training of pedagogical staff in accordance with the policy and ideology of the state (Okoń, 1989, p. 188; 2003, p. 302). Similar decisions were made at other universities, affecting other pre-war scholars.

Key parts of the ideological offensive were changes in education, starting with new education curricula. As we read in a textbook on the history of education, since the school year 1948/49, the assumptions of the didactic-pedagogical work "have been based on materialism in the Marxist-Leninist perspective. An important directive of upbringing has become the development and justification of a belief in the superiority of political, legal, cultural and ethical socialism over capitalism". Thus, "the decisive stage of fights and disputes over 
the ideological and educational direction of the Polish schooling has ended. In the late 1940s, the Polish school was incorporated into the national process of socialist construction" (Mauersberg, 1981, p. 356). The authorities planned to change the school system and carry out a school reform. To achieve this goal, changes in the training of future educators were needed. First, however, inadequate implementation of directives had to be accounted for, and Polish science had to shift to the methodology of dialectic materialism. Such a task was given to the authorities of state universities, and within them, to the newly established pedagogical institutes. Their management required dissociation from the theories of pre-war scholars, whose research had to be criticized. In the language of the authorities, their theories were false and reactionary, proclaimed "under the pressure of petty bourgeois ideology" (Mauersberg, 1981, p. 353). The titles of some of the new papers, created in accordance with the communist authorities' recommendations, speak for themselves: Wychowanie $w$ rodzinie socjalistycznej [Upbringing in a Socialist Family] by Karol Kotłowski, 1949, Przełom musi nastapić [Breakthrough Must Happen] by Aleksander Lewin, 1950, or Reakcyjna teoria nauczania [Reactionary Theory of Teaching] by the above-mentioned Marian Gluth, 1950. As expected by the state authorities, these academic papers included criticism of pre-communist pedagogy, including the cultural pedagogy of scholars like Hessen and Nawroczyński, for its alleged bourgeois and idealistic past. The new state-aligned pedagogy paved the way for a progressive, materialist ideology that would, purportedly, bring about the liberation of the oppressed working and peasant classes in the new reality of the People’s Republic (Okoń, 2003, pp. 300-302). Kotłowski, an heir to this criticized thought, also spoke about the attitude towards pre-war pedagogy, but I will come back to this later.

Apart from pedagogy, the ideological offensive also reached other social sciences and humanities, including philosophy, all the more so because the environment of philosophers very quickly and strongly manifested its resistance to the introduction of Marxism into scholarly research. In 1946, scientists from the Jagiellonian University and the Polish Academy of Arts and Sciences in Kraków expressed their 
stance, saying that "science should be free from ideology and politics" (Mauersberg, 1981, p. 327). Soon, however, a course on Marxism-Leninism was introduced at universities for all students, also later a course on socialist economics. Staff had to be prepared to run these courses ${ }^{1}$. In many officially approved series of scholarly publications between 1945 and 1989, the inclusions and exclusions in texts are quite revealing. The texts are elaborated and edited in close conformity with the educational and scientific policy of the Polish People's Republic. The publications in question include the series of the PWN Biblioteka Klasyków Filozofii (Polish Scientific Publishers' Library of Classical Philosophy), as well as the series of Biblioteka Narodowa (National Library). These latter contain the exemplary editions of the most valuable works of Polish and foreign literature published by the Wydawnictwo Zakładu Narodowego im. Ossolińskich (Ossoliński Institute). The Enlightenment Encyclopédie by Diderot and d'Alembert may serve as an example. In the 1952 Polish edition, under the title Encyklopedia albo stownik rozumowany nauk, sztuk i rzemiost, there were selected entries from the first edition of the encyclopedia, according to a key that leaves no illusions about the profile of this choice. Among many blank spots, the lack of the entry for "education" is noticeable, although we know how important this issue was for the Enlightenment. Moreover, the selection also affected Rozprawa wprowadzajaca wydawców [Publishers' Introductory Dissertation] in this work, from which fragments inconsistent with the binding methodology of dialectical materialism were removed (Encyclopedia, 1952, pp. 8-9). Jan Kott's Wstęp [Introduction] was also written according to the same ideological key and simply makes reading it today difficult. The following decades were used to consolidate Communist power, and pedagogy was practiced in the spirit of Marxism (Wołoszyn, 1964, p. 738). For reasons of space this extensive and many-dimensional topic can be mentioned only in passing here; but it serves to identify the force and extent of the ideological shift

1 I remember that while I was studying pedagogy in the second half of the 80's, both were included in the compulsory study programme. 
accomplished by the Communist authorities. This historical background, moreover, calls for further analysis and theoretical elaboration. But for now, let us turn to the first of the approaches I want to avail of in reviewing Kotłowski's philosophical pedagogy - namely Hannah Arendt's monumental study of totalitarianism.

\section{Hannah Arendt and the Notion of Totalitarianism}

The author of The Origins of Totalitarianism ${ }^{2}$ found the sources of totalitarianism in the condition of contemporary man. Arendt claimed that the keys to understanding the novelty of this form of government were the concentration camps, viewed as laboratories of totalitarian rule, working to change the very essence of humanity. Both Hitler's and Stalin's camps were based on a monstrous lie, the omnipotence of the secret police and the cult of the leader. This form of government was to be distinguished from authoritarian forms by the need to mobilize the masses, the role of official ideology and the lack of pluralism in various areas of life (Grinberg, 1993, pp. 7-24). As Arendt argued, "lawfulness is the essence of non-tyrannical government", while "lawlessness is the essence of tyranny". And if so, "then terror is the essence of totalitarian domination" (Arendt, 1976, p. 464). To this end, terror must eliminate the freedom already attested by "the fact of the birth of man" and whose sense is in its "capacity to make a new beginning" (Arendt, 1976, p. 466). Thanks to lawfulness, she continues, power is legal. In a democratic system, lawfulness "is the stabilizing force"; it sets the boundaries of action but "is insufficient to inspire and guide men's actions". In a totalitarian system, however, the function of laws is taken over by terror, but terror is also "not sufficient to inspire and guide human behaviour" (Arendt, 1976, p. 467). Therefore, convictions, as the human motive for action, must be removed by way of purges. As Arendt wrote, "the aim of totalitarian education has never been to install convictions but to destroy the capacity to form any" (1976, p. 468). And the inhabitants

2 Arendt's books were not during the communist era in Poland published until 1988, when the dissident Independent (uncensored) Publishing House NOWA issued The Origins of Totalitarianism. 
of a totalitarian state must be "thrown into and caught in the process of nature or history for the sake of accelerating its movement; as such, they can only be executioners or victims of its inherent law" (Arendt, 1976, p. 468). The preparation for this double role, instead of a principle of action, is to be ideology.

Writing about ideologies, Arendt, just like Leszek Kołakowski, generally criticized their pseudo-science and pseudo-philosophy, although the attitude of ideologists indicated their scientific and philosophical ambitions. Even though 19th century Weltanschauungen and ideologies did not yet have a totalitarian character for Arendt, she warned that all ideologies can turn totalitarian under the influence of totalitarian movements. As she wrote, "the real nature of all ideologies was revealed only in the role that the ideology plays in the apparatus of totalitarian domination" (Arendt, 1976, p. 470). This can be seen most clearly in relation to 20th century racism and communism, but according to the author of The Origins of Totalitarianism, three totalitarian elements can be seen in every ideology, characterized simply by ideological thinking. They concern, first of all, the ambition of total explanation of past historical events, total knowledge of the present and projections of the future. Secondly, instead of a description of reality based on facts, there appears the art of suspicion, i.e. searching for hidden meanings, conspiracies, impure intentions, etc. In this way, ideological indoctrination is taught at various established educational institutions. Thirdly, there is in ideological thinking the ambition to order facts in an absolutely logical way, based on the premises and deduction "with a consistency that exists nowhere in the realm of reality" (Arendt, 1976, p. 471). Deduction, on the other hand, is understood either logically or dialectically; in this way, ideological thinking could be freed from the burden of experience that was weighing ideologists down. Similar to Arendt, Karl Popper criticized the rules of dialectics in Conjectures and Refutations as part of the theory of falsificationism (1963), as did 
Leszek Kołakowski in his acclaimed critical study Gtówne nurty marksizmu ${ }^{3}$ [Main Currents of Marxism] (1981, Vol. III, pp. 157-163).

Arendt, in her understanding of ideology as a tool of totalitarian movements, discussed also the problem of loneliness (in connection with isolation and impotence), which in the 20th century became "an everyday experience of the evergrowing masses of our century”, further enhanced by a sense of uprooting and superfluity (1976, p. 478) ${ }^{4}$. Without changing the historical context too much, I will move on toward the second theoretical approach, which may be equally useful in understanding the phenomenon of philosophical pedagogy under communism in Poland.

\section{Homo Sovieticus in the Philosophy of Józef Tischner}

Already in the 1960s, Józef Tischner identified invidious practices in the field of education, comprising what he called a totalistic pedagogy. For Tischner, totalism meant the denial of human freedom and the seizure of it by a teacher, parent, or priest, fighting for their authority (Tischner, 1966, pp. 1340-1344, Wrońska, 2019b, pp. 59-64). When this was transferred to the political ground of the communist era and communist power, similar relations were formed between citizens and officials of the ruling party. According to Tischner, the totalistic pedagogy and education scheme was also present in the formation practices in clerical seminars, still far from the spirit of post-conciliar changes in the Catholic Church. What permeated the entirety of these practices was the concept of homo sovieticus - an enslaved man and a client of communism. While examining this issue, Tischner referred to Czesław Miłosz's book Zniewolony umyst [The Captive Mind]. In order

3 Like The Origins of Totalitarianism, Kołakowski's book The Main Currents of Marxism was banned in the Polish People's Republic. The book was first published in 1976 at Instytut Literacki in Paris and in 1981 in Poland as a reprint (samizdat) at an underground publishing house.

4 However, given the scale of this paper, I am only signalling this issue, knowing that from today's perspective - in the face of the COVID-19 pandemic-loneliness is becoming an urgent and important problem in itself, regardless of its link with totalitarian power (although still a fertile soil for it). 
to show the entanglement of people of science and letters that entered into alliances with the authorities. Miłosz undertook to describe the captive mind using specific examples of intellectuals and writers seduced by the communist system (Tischner, 2018, p. 175, Miłosz, 1989, Lilla, 2003). Homo sovieticus is an abstract category but, according to Tischner, everyone is subject to it if they have been exposed to a total ideology for a long time. It is a post-communist form of escape from freedom. The fate of a slave who, after liberation, escapes to become a different slave. Their consciousness determines their existence. As a consequence of the harm suffered, the humiliation experienced, the loss of their place in the world of politics and the threat of losing their job, they will choose to retaliate and say "no", i.e. negate the common good (Tischner, 2018).

According to Tischner, communism would not have been possible without intellectuals. They were a channel through which deceptive speech was flowing into the world, covering the actions of the oppressors. The workers joined the party and the intellectuals supported the doctrine. Those who doubted the perfection of the system deceived themselves by claiming that, despite everything, communism proved to be the only effective form of fight against the threat of fascism and therefore must be accepted. One form of deception is the public confession of belief in communism, the other is the introduction of ideology into one's field of science. Positive science becomes communist when it supports the theses of Marxism-Leninism, the theoretical basis of communism. There is no objective truth, but there are backward and progressive truths, and everyone should engage their forces in the fight for progress. Political reason required that no science should contradict the principles of Marxism-Leninism. All the activities of reason were to be subjected to the power of the political reason. According to Tischner, humanities, more than other sciences, were entangled in ideology. The communists proclaimed that man can only be free in a socialist system, which is a guarantee of human dignity based on the humanism of socialist democracy. "After all” was uttered by liberals, enemies of capitalism, moralists, Christians and Catholics and, of course, also by educators. Thus, scientific reason became an obedient 
servant of political reason. The language of intellectuals was becoming a language full of ambiguity, inhibitions, courting and allusions far removed from direct experience. Even if one belonged to the opposition, the question "where are the limits of a permitted compromise" was like "a splinter in the conscience of an independent intellectual" (Tischner, 2018, p. 182).

Homo sovieticus in Tischner's description was a one-dimensional and terrorized creature. They could not possess, but learned to use, or to possess in such a way that it was not known that they possessed. As a client, they consumed not only the means of temporal life, but also the means to secure eternal life, and so they penetrated into the party as well as into the churches. Tischner describes homo sovieticus as being "always full of claims, ready to blame others and not themselves, morbidly suspicious, saturated with awareness of misery, unable to sacrifice themselves, they went from Wawel to Jasna Góra and back again as an annoyance and remorse of the priests" (Tischner, 2018, p. 189). Christianity approached communism as a version of European neopaganism. It wanted to overcome it, not simply inflict defeat on it by seeing itself mixed up in pagan superstitions. In this description, attention is drawn not only to the mechanism of subjugation of society by the power, but also to the effects it leaves for the longer term in that society. In Tischner's opinion, the Polish overcoming of communism has not been finished, because it brought up a whole multitude of clients, both in the party and outside of it: sovietized people deprived of a sense of responsibility. Pedagogy contributed to this malign order of things, preparing teaching staff, educators and parents for over 40 years of Communism in Poland.

\section{Philosophy and Ideology in Sergei Hessen's View}

The third theoretical approach, historically foregoing those presented, is related to Sergei Hessen's concept of pedagogy of culture. $\mathrm{He}$ developed it in the interwar period, calling it personalistic and treating it as an applied philosophy. It was inspired by neo-Kantianism, which he came across during his philosophical studies in Germany. According to this concept, he understood education (including upbringing) 
as a spiritual process "in which the personality of man is fulfilled and at the same time the continuity of cultural tradition is ensured" (Hessen, 1939, p. 6). In the course of it, the human being is incorporated into the world of cultural values, passing through the stages of existence from anomy, through heteronomy, to autonomy (voluntary submission to the higher principle). Hessen made a very clear distinction between philosophy and ideology. While the former is distinguished by its aporetic character, i.e. the realization of difficulties (contradictions in our view of the world), as well as openness and dynamism, born out of the spirit of protest against the prevailing worldview, the latter is placed on the opposite side. It is a transformed worldview with a distinctive sense of certainty, closed, exclusive and party-related. Secondly, philosophy uses doubt as a tool to achieve the truth, while ideology is characterized by a lack of surprise and little or no awareness of ignorance. Thirdly, the former does not reject different worldviews but starts a dialogue and argues, while the latter rejects any opposing viewpoints and any problems they might highlight. Philosophy is distinguished by its attitude of surprise and its awareness of ignorance; lust for power is foreign to it. Ideology, however, is fixed in dogma, wants to vanquish through coercion. Finally, Hessen points out the dangers of transforming philosophy into ideology. This happens when, in philosophical thinking, the tension disappears between the truth being enclosed in a worldview and the full truth rising above being (Hessen, 1939).

In this philosophy of education (including upbringing), the concept of worldview stands out. It means an individual view of the world, which in the process of man's spiritual development is overcome in a creative act of personality, assuming the form of a cultural world. It becomes a creation of an objective spiritual world (as philosophy, science, law, morality, religion, art). In turn, when the worldview insists on its distinctiveness, then it degenerates into an ideology and requires recognition through coercion. In Hessen's argument philosophical pedagogy was part of an objective spiritual world, while ideological pedagogy was already an emanation of ideology itself (Hessen, 1939, Wołoszyn, 1998). 


\section{Karol Kotłowski - Profile and Pedagogical Activity in the People's Republic of Poland}

As a student of Hessen, Karol Kotłowski naturally aspired to continue his master's school of thought, but after the removal of Hessen from the chair of general pedagogy in 1948 and handing it over to Gluth, Kotłowski developed his concept of pedagogy first in the Department of the History of Education (1947-1951). Then as head of the Department of Pedagogy (1958-1970), in time assuming senior positions as director of the institute (1970-1975) and faculty dean (1970-1972) and finally as head of the Department of Theory of Education (1972-1980). He wrote a text in 1976 on philosophical pedagogy in the University of Łódź during three decades of the Polish People's Republic (Kotłowski, 1976b). An exploration of this manuscript may help in disclosing Kotłowski's real position. At the very beginning, the author explains that philosophical pedagogy should not be comprehend as a separate trend, because "no direction of pedagogy can ignore philosophy”. After all, "only philosophy can explain to the educator the meaning of his work" (Kotłowski, 1976b, p. 120). In this sentence, Kotłowski declared his loyalty to the ideas of Hessen, a world-renowned cultural philosopher. Going further, in accordance with the historical criterion, he divided philosophical pedagogy into pre-Marx and Marxist pedagogy. The former was not a monolith, i.e., a unified doctrine; on the contrary, it represented various trends, including the humanities, practised by e.g. pedagogues of culture (Hessen, Nawroczyński). But, as he says, "the full victory of socialist pedagogy could have been achieved, among other things, by fighting the old pedagogy" (Kotłowski, 1976b, p. 120). There were three possible ways of dealing with the heritage of cultural pedagogy, i.e.: accepting and continuing it, rejecting it because it is incompatible with the ideology of Marxism, or overcoming it with the Marxist philosophy. The first way, according to Kotłowski, was unacceptable for ideological and material reasons (he judged that in Hessen's version there were supposedly some deficiencies, while in Nawroczyński's version there were fewer, but still a revision was needed from the point of view of Marxist pedagogy). The second way would also be inappropriate, given the merits of its creators for pedagogy (such as 
extremely important analyses of freedom and coercion); it would be, as he admitted, a mistake and impoverishment of the mentality of pedagogy graduates. There was only the third possibility left: to overcome it (Śliwerski, 2001). This was also the path Kotłowski chose when he decided to pursue philosophical pedagogy, showing the philosophy of dialectical materialism, i.e. Marxism, as a perspective in which all the earlier philosophical thought culminates. He consistently applied this version by building an axiological basis for the theory of upbringing, based on the personality model of a socialist builder, a system of socially recognized norms, based on ideas generated by ideology and the scientific worldview as a set (conglomerate) of intellect, feelings and will. Kotłowski's choice of the third strategy allows us to see, on Arendt's analysis, the application of dialectics as a variety of ideological thinking. The new normativity of socialist pedagogy, accomplished through overcoming idealistic bourgeois philosophy, is also reminiscent of the strategy of the Church, building its doctrine on overcoming communism as a variation of European neo-paganism.

\section{Axiological Bases of Karol Kotłowski's Pedagogy}

It is worthwhile at this point to take a closer look at the ideas, values and norms that are the distinguishing features of Kotłowski's normative socialist pedagogy (1976a). This pedagogy presents an ideological rather than philosophical justification for the presence of values in education (cf. Cichon, 1980). The author admits that axiology, with its different stances, aroused suspicion of Soviet ethicians, but Marxist pedagogy needed a reference to values. The concepts used thus far guarded the interests of the class ruling the society. After the victory of the proletariat, it has the right to impose its system of moral values, with the difference that proletarian norms are created for all working and wronged people. Not relativism (of which certain stances are accused), but perfectionism, the conviction that ethical norms and people are constantly improving, is the position of Marxist ethics. Despite their durability, their functionality is determined by class standards. Proletarian humanism recognises the primacy of the group over the individual; its greatest enemy is private property. Collectivism does 
not oppose the individual personality to the society, but connects them dialectically, making it possible to identify a mortal personality with an immortal society. This is the first pair of ethical ideas of the socialist state. The second pair, according to Kotłowski, are: patriotism - internationalism, the third: work - conscious discipline and respect for social property. Together they are determinants of the norms governing relations between people inside and outside countries. These ideas are an amalgamated and commonly accepted set, the source of norms (obligations and prohibitions) regulating mutual relations among people. If, in turn, one considers "as adequate the definition of the worldview as a set of beliefs in relation to the objective and subjective world determining human activity", then the discussion on the independence of ethics from worldviews becomes, according to Kotłowski, pointless. All "action that is conscious and relevant to the personality, i.e. primarily action judged in ethical terms, is dependent on the ideology and worldview adhered to" (1976a, p. 69).

Going further, the postulated model of the builder of socialism is based on the universally binding value system. When bringing up a child, one should not wait until the child grows up to various values. Hessen and Nawroczyński, as we remember, described phases of moral development from anomy through heteronomy to autonomy, and the allocation of animal, normative and absolute values to particular phases. But this was, according to Kotłowski, "overly subordinated to philosophy" (1976a, p. 86). As he argued, all three pairs of norms must be made available from the very beginning, only in an age-appropriate manner. Humanism, according to him, is the ethical value of our whole civilization; it has many contact points with Christianity, the only difference being in private property. In turn, the model of a teacher-educator must submit to the rigors set by a responsible group of people who form the state "in the spirit of socialist ideology" and cannot "decide individually on the basis of their conscience what is true and what is false, what is right and what is wrong. Then the teacher would become an anarchizing factor for the youth, not an educator" (1976a, p. 180). In accordance with the teacher's distinctive feature, i.e. devotion to the idea, they should be convinced that socialism, 
for which they work, "is the source of the most perfect system of ethical values that modern mankind can create, and that making it a reality on a global, human scale will bring happiness [...] it is their duty to be a socialist themselves and to educate young people entrusted to them in this spirit" (1976a, p. 183). The educator is also to be responsible for the pedagogical training of parents in order to overcome the contradiction between family and school, and to promote complementarity between the two environments. But still, the dominant role is played by the school, which is "an institution fighting to strengthen" the system of ethical values of socialism in people's consciousness (1976a, p. 196).

\section{Kotłowski's Philosophical Pedagogy in the Service of Ideology}

Reading Kotłowski, one can see, of course, that while being deeply rooted in philosophical thought, he is also dominated by his support for the ideology of the socialist state, which demands that pedagogy serve to the system and prepare children for being system builders. Upbringing, understood as moulding the new man, becomes the primary goal. It will outweigh education, which will lose the status of an autonomous goal as in Hessen. The teacher is supposed to be an ideological guide, has indoctrination at his disposal, although Kotłowski will consider it unnecessary in socialism. The revolution has already happened and it is enough to build on the claims of the scientific worldview.

However, Kotłowski's search for an agreement with the ideology of the state did not succeed fully in making pedagogy a passive instrument or a servant to the system. It should be remembered that it was among the pedagogues at the University of Łódź, after the political changes in 1989, that the initiative to establish the Society of Philosophical Pedagogy was born, also with Kotłowski's achievements in mind. On the other hand, there is no doubt that such pedagogy served the state and its ideology. Each text by Kotłowski presents Marxism as the culmination of historical transformations where everything comes true, all contradictions are removed and conflicts are resolved. Referring directly to the ideology of the socialist state which brings happiness to its citizens is a declaration and willingness of an intellectual to serve it in his scientific workplace. Kotłowski's rejection of indoctrination - a key 
instrument of totalitarian and communist power - may indicate his conflicted attempts to negotiate a way in a difficult situation: involving survival, conformism, or a search for compromise.

Moreover, when analyzing Kotłowski's achievements, it stands out that only one text does not take up his usual theme of upbringing. It is a text about schools in England after World War II, published in 1960. And although it is based on texts on education, the author aptly recognizes that these refer to instruction/teaching and not to upbringing young English people. And its final message, based on Spencer's phrase ("The old must continue so long as the new is not ready, this perpetual compromise is an indispensable accompaniment of a normal development"), is a confirmation and approval of the English education system, which is developing through evolution, allowing "dead branches to exist in education but taking care of the young shoots as well" (Kotłowski, 1960, p. 162). In his other works (e.g. Problemy wychowania w rodzinie, 1966, Filozofia wartości a zadania pedagogiki, 1968, O pedagogicznym ksztatceniu rodziców, 1968, Rzecz o wychowaniu patriotycznym, 1974, Aksjologiczne podstawy teorii wychowania moralnego, 1976) Kotłowski's attention is focused on upbringing. However, it would be difficult to find in them his own, philosophically well-established definition of upbringing. This is because he assumes a single, problem-free interpretation of upbringing, as a way of moulding the personality of pupils according to the model and goals adopted in the socialist society, which was in force in the communist pedagogy for many years (e.g. Kotłowski, 1976a, p. 73). Upbringing has been defined in the Pedagogical Dictionary by Wincenty Okoń as a deliberately organized human activity aimed at "inducing specified changes in human personality” (1975, p. 333; 1992, p. 233). In Kotłowski's case, we find a justification for such an understanding of upbringing, optimally implemented in the "spirit of the socialist ideology" (1976a, p. 180), both in the family and at school. This was, for Kotłowski, an upbringing leading to collective freedom and introduction to self-discipline, cleared of the contradictions in which freedom was entangled in the bourgeois pedagogy (1968, pp. 156-186). 


\section{Conclusion}

This review of Kotłowski's approach illustrates that while he sought to claim the standing of philosophy, his writings served the political reason of the communist authorities. This emphasis prevailed through the whole official pedagogy in the Polish People's Republic. Fortunately, the circle of power was not so strong as to rule out other pedagogical positions that did not conform to Marxist ideology (Friedrich \& Brzeziński, 1965). As Tischner wrote, there was also an intellectual opposition that applied one of two attitudes: it either nurtured pure scientific objectivity, or openly criticised the very foundations, exposing the lies of the system and its crimes. But this is another story that can only be briefly indicated here.

Paradoxically, all the extensive knowledge about upbringing collected by pedagogical research, including Kotłowski's philosophical pedagogy, may prove to be a fund of promising sources for tackling a new generation of threats to education in the policy reforms of neoliberal governments internationally (Wrońska, 2008, 2019a). As a result, even recognised philosophers, such as Alasdair MacIntyre, make judgements about education in the sense of teaching as a set of skills and not as a social practice with its own internal goods that develop its participants (MacIntyre \& Dunne, 2004). Instrumentalization of education is a new version of subordinating it to the state and its goals (in this case economic but also ideological, e.g. religious, national and other). Today's tendencies in politics, not only in Poland: the turn towards nationalism, criticism of liberal democracy (Zielonka, 2018) increasing authoritarianism, intolerance and xenophobic social moods, allow us to see some ominous similarities to the ideologies of the 20th century. In this regard the ideology-infused origins of totalitarianism demonstrated by Arendt provide a salutary warning.

Tischner's concept of homo sovieticus is useful when we think about the risk of a recurrence of similar opportunistic adaptation strategies in our society. So it is also a warning, especially for pedagogy (particularly when it weakens its relationship with philosophy). At the same time, it shows well the very attitudes that many of our compatriots had and that helped the authorities to rule according to the prevailing 
ideology. Totalitarianism in Arendt's view plays a similar role but can be a warning not only for post-communist countries.

Answering the question of how to prevent the recurrence of totalitarianism, with the participation of pedagogy, my proposals are following: one relates to politics and the state, or the surroundings of pedagogy, the other - to pedagogy itself. Firstly, it is worth rebuilding trust in liberal democracy as a system that fosters the development and autonomy of individuals within civil society. A political philosophy that is in thrall to the excesses of neoliberalism and nationalism is far from conducive to this undertaking. Secondly, in pedagogy itself, it is worth pursuing in-depth philosophical reflection on education (including upbringing) in parallel with empirical research on the quality of learning. The latter cannot replace the former and is likely to be diminished without it.

\section{References}

ARENDT, Hannah, 1976. The Origins of Totalitarianism. San Diego, New York, London: A Harvest Book Harcourt Brace \& Company.

BREN, Paulina \& NEUBURGER, Mary (eds.), 2012. Communism Unwrappted. Consumption in Cold War Eastern Europe. Oxford: Oxford University Press. ISBN 978-0199827671.

CICHOŃ, Władysław, 1980. Aksjologiczne podstawy teorii wychowania [Axiological Fundations of Theory of Upbringing]. Kraków: Wydawnictwo Uniwersytetu Jagiellońskiego.

FRIEDRICH, Carl J. \& BRZEZIŃSKI, Zbigniew K., 1965. Totalitarian Dictatorship and Autocracy. 2nd edition, Revised by Carl J. Friedrich. Cambridge, Mass.: Harvard University Press.

GIUSTINO, Cathleen M., PLUM, Cathreen J. \& VARI, Alexander (eds.), 2013. Socialist Escapes - Breaking Away from Ideology and Everyday Routine in Eastern Europe, 1945-1989. New York, Oxford: Berghahn Books. ISBN 978-0-85745-669-4.

GRINBERG, Daniel, 1993. Wstęp do wydania polskiego [Preface to Polish Edition]. In: ARENDT, Hannah. Korzenie totalitaryzmu [The Origins of Totalitarianism]. Warszawa: Niezależna Oficyna Wydawnicza, pp. 7-24.

HEJNICKA-BEZWIŃSKA, Teresa, 2015. Pedagogika. Podręcznik dla pierwszego stopnia ksztatcenia na poziomie wyższym [Pedagogy. A Textbook for the First Degree of Higher Education]. Warszawa: Difin SA. ISBN 978-83-7930-925-2. 
HESSEN, Sergiusz, 1939. O sprzecznościach i jedności wychowania [On Contradictions and Unity of Education]. Lwów-Warszawa: Książnica-Atlas.

KLICH-KLUCZEWSKA, Barbara. 2017. Biopolitics and (Non)-Modernity. Population Micro-Policy, Expert Knowledge and Family in Late-Communist Poland. Acta Poloniae Historica. No. 115, pp. 151-174. DOI http://dx.doi.org/10.12775/ APH.2017.115.06.

KOŁAKOWSKI, Leszek, 1981. Główne nurty marksizmu [Main Currents of Marxism]. ALTERNATYWY.

KOTŁOWSKI, Karol, 1976a. Aksjologiczne podstawy teorii wychowania moralnego [Axiological Fundations of Theory of Moral Upbringing]. Wrocław: Zakład Narodowy im. Ossolińskich - Wydawnictwo.

KOTŁOWSKI, Karol, 1968. Filozofia wartości a zadania pedagogiki. [Philosophy of Values and the Tasks of Pedagogy]. Wrocław: Zakład Narodowy im. Ossolińskich Wydawnictwo.

KOTŁOWSKI, Karol, 1976b. Pedagogika filozoficzna na Uniwersytecie Łódzkim w Trzydziestoleciu Polski Ludowej [Philosophical Pedagogy at the University of Łódź in the Thirty Years of Polish People's Republic]. Acta Universitatis Lodziensis. Nauki Humanistyczno-Społeczne. Łódź, Series I, No. 14, pp. 119-134.

KOTŁOWSKI, Karol, 1974. Rzecz o wychowaniu patriotycznym. [On Patriotic Upbringing]. Wrocław: Zakład Narodowy im. Ossolińskich - Wydawnictwo.

KOTŁOWSKI, Karol, 1960. Szkoła angielska po drugiej wojnie światowej [English School after the Second World War]. Warszawa: Państwowe Zakłady Wydawnictw Szkolnych.

KOTT, Jan, 1952. Wstęp [Introduction]. In: Encyklopedia albo stownik rozumowany nauk, sztuk i rzemiost. (Wybór) [An Encyclopedia or a Dictionary of Sciences, Arts, and Crafts. (Selection)]. Wrocław: Wydawnictwo Zakładu Narodowego im. Ossolińskich, pp. III-XLII.

KOZŁOWSKI, Władysław M., 1932. Co i jak czytać? Wykształcenie samego siebie i drogi do niego [What and How to Read? Self-education and the Path to It]. 6th edition. Warszawa: Gebethner i Wolff.

LILLA, Mark, 2003. The Reckless Mind. Intellectuals in Politics. New York Review Books. ISBN 978-1590170717.

MACINTYRE, Alasdair \& DUNNE, Joseph, 2004. Alasdair MacIntyre on Education: In Dialogue with Joseph Dunne. In: DUNNE, Joseph \& HOGAN, Pádraig (eds.). Education and Practice: Upholding the Integrity of Teaching and Learning. Oxford: Blackwell Publishing. ISBN 978-1-405-10894-2. 
MAUERSBERG, Stanisław, 1981. Rozwój oświaty w Polsce Ludowej [Development of Education in the Polish People’s Republic]. In: MIĄSO, Józef (ed.). Historia wychowania. Wiek XX [History of Education. 20th Century]. 2nd edition. Warszawa: PWN, Vol. 1, pp. 279-431.

MIŁOSZ, Czesław, 1989. Zniewolony umyst [The Captive Mind]. Kraków: Krajowa Agencja Wydawnicza.

OKOŃ, Wincenty, 1975 [5th edition 1992]. Stownik pedagogiczny [Pedagogical Dictionary]. Warszawa: Państwowe Wydawnictwo Naukowe .

OKOŃ, Wincenty, 2003. Szkic problemu: miejsce pedagogiki w polityce [Sketch of the Problem: the Place of Pedagogy in Politics]. In: SZTOBRYN, Sławomir \& ŚLIWERSKI, Bogusław (eds.), 2003. Idee pedagogiki filozoficznej [Ideas of Philosophical Pedagogy]. Łódź: Wydawnictwo Uniwersytetu Łódzkiego, pp. 297-310. ISBN 83-7171-682-6.

OKOŃ, Wincenty, 1989. Zarys autobiografii naukowej [An Outline of a Scientific Autobiography]. Kwartalnik Historii Nauki i Techniki. Warszawa: Wydział Historyczny Uniwersytetu Warszawskiego, Vol. 34/2, pp. 177-216.

POPPER, Karl, 1963. Conjectures and Refutations. The Growth of Scientific Knowledge. London: Routledge \& Kegan Paul.

SZULAKIEWICZ, Władysława, 2006. Historia oświaty i wychowania w Polsce. 1944-1956 [History of Education in Poland. 1944-1956]. Kraków: Wydawnictwo WAM. ISBN 83-7318-777-4.

ŚLIWERSKI, Bogusław, 2001. Pedagogika filozoficzna - normatywna [Philosophical-Normative Pedagogy]. In: Wspótczesne teorie i nurty wychowania [Contemporary Theories and Currents in Education]. 2nd edition. Kraków: Oficyna Wydawnicza „Impuls”, pp. 47-60. ISBN 83-86994-90-8.

TISCHNER, Józef, 2018. Etyka solidarności oraz homo sovieticus [Ethics of Solidarity and Homo Sovieticus]. Kraków: Wydawnictwo Znak. ISBN 978-83-240-5362-9.

TISCHNER, Józef, 1966. Z problematyki wychowania chrześcijańskiego [On the Issues of Christian Upbringing]. Znak. No. 11, pp. 1335-1345.

WOŁOSZYN, Stefan, 1964. Dzieje wychowania i myśli pedagogicznej w zarysie [An Outline of the History of Education and Pedagogical Thought]. Warszawa: PWN.

WOŁOSZYN, Stefan, 1998. Nauki o wychowaniu w Polsce w XX wieku [Educational Sciences in Poland in the 20th Century]. 2nd edition. Kielce: Dom Wydawniczy STRZELEC.

WROŃSKA, Katarzyna (ed.), 2019a. Dobra edukacji i ich pedagogiczna eksploracja [The Educational Goods and their Pedagogical Exploration]. Kraków: Wydawnictwo Uniwersytetu Jagiellońskiego. ISBN 978-83-233-4807-8. 
WROŃSKA, Katarzyna, 2008. Dobra wewnętrzne praktyki życia rodzinnego i ich moralne ugruntowanie [Family Life as a Practice with their Internal Goods and Moral Foundation]. In: MUCHACKA, Bożena (ed.). Rodzina w kontekście wspótczesnych problemów wychowania [Family in the Context of Modern Problems of Upbringning]. Kraków: Wydawnictwo Naukowe PAT, pp. 55-65. ISBN 978-83-7438-154-3.

WROŃSKA, Katarzyna, 2019b. Education and Freedom. An Essay on Józef Tischner's Pedagogical Thought. Filozoficzne Problemy Edukacji. Kraków: UJ, No. 2, pp. 49-65. DOI 10.4467/25450948FPE.19.004.10958.

WROŃSKA, Katarzyna, 2020. Samouctwo - w myśli pedagogicznej i życiu Władysława M. Kozłowskiego [Self-Instruction - in Pedagogical Thought and Life of Władysław M. Kozłowski]. In: SZTOBRYN, Sławomir \& DWORAKOWSKA, Katarzyna (eds.). Wielogłos w myśli o wychowaniu. 100 lat polskiej pedagogiki filozoficznej [A Polyphony in Thought of Education. 100 Years of Polish Philosophical Pedagogy]. Warszawa: Wydawnictwa Uniwersytetu Warszawskiego, pp. 24-42. ISBN 978-83-235-4246-9.

ZIELONKA, Jan, 2018. Counter-Revolution: Liberal Europe in Retreat. Oxford: Oxford University Press. ISBN 978-0198806561. 